\title{
Anglo-français: philologie et linguistique, sous la direction d'Oreste FLOQUET et Gabriele GIANNINI
}

\section{Walter Meliga}

\section{OpenEdition}

\section{Journals}

\section{Edizione digitale}

URL: http://journals.openedition.org/studifrancesi/14857

DOI: 10.4000/studifrancesi. 14857

ISSN: 2421-5856

\section{Editore}

Rosenberg \& Sellier

\section{Edizione cartacea}

Data di pubblicazione: 1 décembre 2018

Paginazione: 472

ISSN: 0039-2944

\section{Notizia bibliografica digitale}

Walter Meliga, «Anglo-français: philologie et linguistique, sous la direction d'Oreste floquet et Gabriele GIANNINI», Studi Francesi [Online], 186 (LXII | III) | 2018, online dal 01 janvier 2019, consultato il 06 janvier 2021. URL: http://journals.openedition.org/studifrancesi/14857 ; DOI: https://doi.org/10.4000/ studifrancesi. 14857

Questo documento è stato generato automaticamente il 6 janvier 2021.

\section{(†)

Studi Francesi è distribuita con Licenza Creative Commons Attribuzione - Non commerciale - Non opere derivate 4.0 Internazionale. 


\title{
Anglo-français: philologie et linguistique, sous la direction d'Oreste FLOQUET et Gabriele GIANNINI
}

\author{
Walter Meliga
}

\section{NOTIZIA}

Anglo-français: philologie et linguistique, sous la direction d'Oreste FLOQUET et Gabriele GIANNINI, Paris, Classiques Garnier, 2015, «Rencontres 119. 'Civilisation médiévale' 13», $162 \mathrm{pp}$.

1 Il volume raccoglie le comunicazioni di una giornata di studio romana sull'anglonormanno, che aveva lo scopo di far dialogare filologi e linguisti sul tema, nel tentativo anche di rivitalizzare la ricerca italiana in questo campo sulla scia delle numerose iniziative che interessano il francese d'Inghilterra, in volume e sulla rete. I saggi inclusi sono i seguenti: D. BURRows, Vers une nouvelle édition de l'Apocalypse en prose (pp. 9-34); M. CARERI e M. LACANALE, Accents et syllabes dans les manuscrits anglo-normands (pp. 35-44); 0. FLOQUET, La première personne non-standard en anglo-français. Sur les types jo vienc, jo vinc, jo erc (pp. 45-61); G. GIANNINI, Guides de pèlerinage, Orient latin et anglo-français (pp. 63-90); R. INGHAM, John Gower, poète anglo-normand. Perspectives linguistiques sur "Le Myrour de l'Omme" (pp. 91-100); A. LANDOLf, Un regard à rebours. D'Élisabeth Tudor à Marie de France (pp.101-118); G. PARADISI, Les "Folies", les premiers romans tristaniens et l'Angleterre. Remarques sur la transmission des textes (pp.119-134); D. TROTTER, «Trouvé l'avum mis en tist». Comment réduire notre ignorance du lexique de l'anglo-normand (pp. 135-150). 